\title{
点滅周期および色光の変化による 生理的・心理的影響十
}

\author{
山下 真裕子 $* 1 \cdot$ 山田 逸成 $* 2$ 安田 昌司 $* 3$
}

\begin{abstract}
点滅周期を変化させた色データにおける生理的・心理的影響を検討することを目的に, 学生16名を対象 に実験を行った。矢の結果，点滅周期の違いによる脳波の $\alpha 3$ 分布率および主観評価に有意差を認めた。 つまり長周期の点滅周期の点滅光に快適性やリラックス感が高まる傾向を認めた。今回得られた結果によ り，ストレスに起因する心身の不定愁訴を抱える人々に対し，病院や企業，教育現場，地域社会において 癒し効果の高い快適空間に提供することが可能と考えている.
\end{abstract}

キーワード : 色光, 点滅周期, 生理的・心理的影響

\section{1. 緒言}

現代社会は長期にわたる不況・リストラなどによっ て生活のゆとりが培失し, うつ病や心身症などのスト レスに関連した疾患は増加の一途を辿っている。それ ゆえ，より一層癒し効果に対する要求が高まってい る。午の中で，日常生活において『視覚』の果たす役割 は極めて大きく, 形状, 大きさ, 色(色光), 輝度, コ ントラスト，動きなど様々な要素がある。これらが組 み合わさることにより視覚的な呈示物として，それを 観察する人間に対し，快・不快や情動などといった心 的な活動を生じさせることが可能とされている。なか でも色や色光が心理的に与える影響に関する研究は数 多く行われ，赤色には交感神経の活性作用，緑色には 感情的反応の鎮静作用，青色には自律神経のバランス を保つことが明らかにされている[1-9]。

このように色光には, 交感神経や副交感神経を活性 化する作用を有し，それらの作用を巧みに応用した製 品が開発・商品化されている。中でも, 副交感神経を 活性化し「癒し効果」や「リラックス効果」などの作用を 及ぼす照明やプラネタリウム等が注目を集めている $[10,11]$. 特に近年では，自然界の信号に含まれる「ゆ

\footnotetext{
$\dagger$ Psychophysiological effects of colored lights for change of flashing cycle

Mayuko YAMASHITA, Itsunari YAMADA and Masashi YASUDA

* 1 神奈川県立保健福祉大学 保健福祉学部

School of Nursing, Kanagawa University of Human Services

$* 2$ 滋賀県立大学 工学部

School of Engineering, University of Shiga Prefecture

*3 滋賀県立大学産学連携センター

Center of University-Industry Cooperation, University of Shiga

Prefecture
}

らぎ」の特徴を模倣し，家電機器などの制御に応用し ようとする研究が行われており, 実用化の事例も幾つ か存在する。一般的に, ホタルや暖炉，ロウソクの炎 といった自然界の動きのある光が, 我々に安らぎや心 地よさを感じさせることが知られている $[12-16]$ 。こ の要因の 1 つとして周波数とパワースペクトルが反比 例する $1 / f$ ゆゔの影響とされており，人に安らぎ， 心地よさ，自然さ，快適感などを与える信号には，こ のような特性を持つ $1 / f$ ゆぎが含まれると報告され ている $[17,18]$ 。これまで, 実物のホタルを使用した 心理評価や，発光ダイオード (Light Emitting Diode; LED)に $1 / f$ ゆらぎの特性を導入した擬似光を作り， 心理的評価が行わ机ているが $[17,18]$, そのような光 源では色光の制御が困難であるため, 点滅周期および 色相を変化した点滅光の呈示における心理的・生理的 影響を調べた研究は充分になされていなかった。

本研究ではホタルの光で見られる周期的な点滅光や ゆらぎに着目し, 色光や点滅周期を変化させ, 生理 的・心理的影響について検討した。これまで，我々は 視感度の高い暗視野で液晶ディスプレイが発する色光 を使用して, 明度や彩度別による生理的・心理的影響 の違いを見出してきた $[19,20]$ ，そこで本研究では， その研究で使用した色光と環境を活用し, 黄, 赤, 緑，青の 4 色光における点滅周期を变化した各色光の 心理的・生理的影響を調べ，各データの相関について も調べた。 


\section{2. 研究方法}

\section{1 対象}

被験者は, A 大学に在籍する 20 22歳の学生 16 名 で，事前に口頭拉よび書面により説明を行い，同意を 得た学生とした。対象者の平均年齢は 21.4 (SD 0.73) 歳で，全員が男性であった。また，全被験者は色覚異 常やてんかんの既往はなく，体調は普通～良好の状態 であった．事前に過去の色覚異常の指摘の有無につい て人権に配慮した上で確認を行った。さらに実験後， 実際の色データをディスプレイ上で確認しながら黄色 光, 赤色光, 緑色光, 青色光それぞれの周期を変化し た点滅光に対する感想やコメントを聴取した。その内 容から, 明らかな色覚異常は認められないと判断し た。また食事による影響を除くため，実験前 2 時間は 飲食を避けるように指示した。

\section{2 実験環境}

明所と暗所で人間の色光に対する見え方は変化し， 暗所視では 2 倍以上の感度となることから $[21]$, 本研 究では, 視感度を効果的に高められるように $0.1 \mathrm{x}$ 以 下の暗室を用意し，実験前の暗順応時間は最低30分を 確保した。実験室内は壁面および床面がアイボリー色 の色彩環境であり，被験者とディスプレイの距離は $50 \mathrm{~cm}$ に設定した。物理的ストレスによる影響を回避

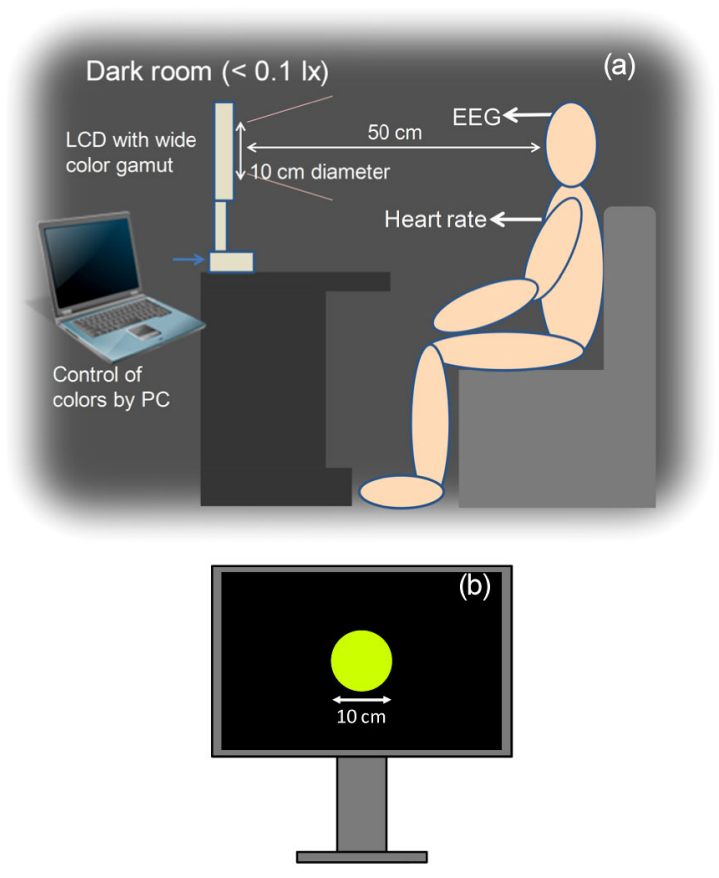

図 1 実験環境 (a)とディスプレイの表示図 (b)
するため，室温は $18 \sim 22^{\circ} \mathrm{C} ，$ 湿度は $40 \sim 60 \% に$ に設定 した。呈示刺激は, 解像度は $1680 \times 1050$ ，フレーム周 波数は $47.5 \sim 61 \mathrm{~Hz}$ の広色域液晶ディスプレイ (ColorEdge CG223W; Eizo Nanao Corp.)を用いた。被験者はパソ コンで制御した広色域液晶ディスプレイから表示され る $10 \mathrm{~cm}$ (視角 11.5 度) 径の点滅光を注視し, 呈示刺激 による生理的および心理的影響を検討した(図 1 ).

\section{3 呈示刺激}

本実験では, 黄, 赤, 緑, 青の点滅光を呈示刺激と して使用し, 色度計にて, 各色光の色度と輝度を数值 化した(表 1 )。色度はCIE1931表色系での xy 色度座 標で示している. 赤, 緑, 青の色光は色相による差異 を顕著にするため, 前研究で使用した中で最も彩度の 高い色光 (vivid) を用いた $[19,20]$. 黄色光については 将来的にホタルの環境を目的とするため，ホタルが発 する色光に近い黄色光 (黄緑に近い黄色)を選んでい る.

点滅光の周期は1.2秒，2.4秒，4.2秒について検討し た。 なお黄色光以外の色光の点滅周期は, 被験者の負 担を考慮し 1.2 秒，4.2秒のみ検討した。各点滅では, ホタルの光に倣って図 2 に示すように, 徐々に光強度 を高める，そして弱めるように設定した (B\&Wtek 社

表 1 実験で用いた色光（黄, 赤, 緑, 青) の輝度 (Luminance) と色度 $(\mathrm{x}, \mathrm{y})$

\begin{tabular}{|c|c|c|c|}
\hline & \multirow{2}{*}{$\begin{array}{c}\text { Luminance } \\
\left(\mathrm{cd} / \mathrm{m}^{2}\right)\end{array}$} & \multicolumn{2}{|c|}{ Chromaticity coodinate } \\
\cline { 3 - 4 } & 6.51 & 0.38 & $y$ \\
\hline Yellow & 2.85 & 0.63 & 0.55 \\
\hline Red & 1.78 & 0.21 & 0.32 \\
\hline Green & 0.59 \\
\hline Blue & 0.36 & 0.16 & 0.09 \\
\hline
\end{tabular}

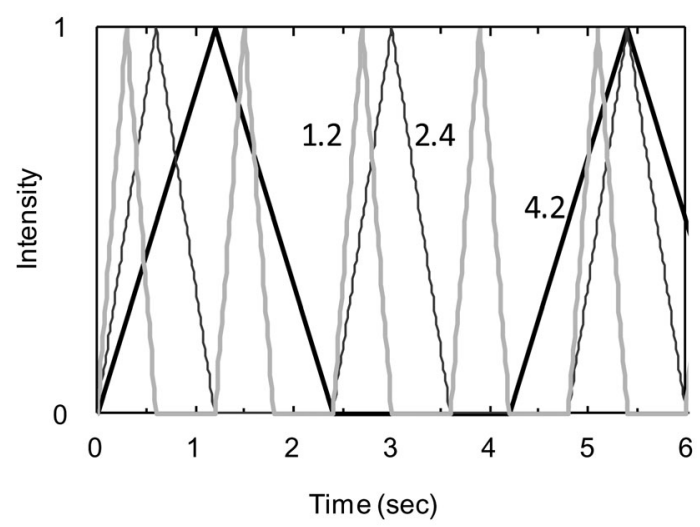

図 2 実験で用いた点滅光の点滅周期（1.2 秒，2.4 秒， 4.2 秒) 
製マルチチャネル分光器 Glacier X で強度変化を確認 している)。[14-18]また，いずれの点滅光に一定時 間の暗状態(呈示時間とほぼ同等の時間)を挿入してい る.

各点滅光をランダムに 1 分間表示した。残像効果を 回避するため，各刺激間のインターバルを十分にとっ た．インターバル時はディスプレイ上には何も表示せ ず，極力刺激のない環境を整えた。なお，用いた点滅 光は前に呈示した色光による影響を防ぐため, 各色光 の輝度は最も高輝度時で $10 \mathrm{~cd} / \mathrm{m}^{2}$ 未満とした (表 1 ).

\section{4 評価指標}

\subsection{1 生理的指標}

大脳機能の評価指標として脳波, 自律神経系の評価 指標として心拍数を採用した。本研究ではフューテッ クエレクトロニクス株式会社製の脳波計と心拍計を使 用した。脳波の測定では，5つの中心周波数 $(\theta$ 波5.0 $\pm 1.0 \mathrm{~Hz}, \alpha 1$ 波7.5 $\pm 0.5 \mathrm{~Hz}, \alpha 2$ 波 $10.0 \pm 1.0 \mathrm{~Hz}, \alpha 3$ 波 $12.5 \pm 0.5 \mathrm{~Hz}, \beta$ 波 $22.0 \pm 8.0 \mathrm{~Hz})$ を用い, データ解析に は同脳波計用解析ソフト・パルラックス II を用いた. 解析対象脳波は $\alpha 1$ 波, $\alpha 2$ 波, $\alpha 3$ 波, $\theta$ 波, $\beta$ 波とし, 解析には各 60 秒間の視覚刺激暴露中の 1 秒毎の各脳波 の分布率(単位時間あたりの各脳波の電圧を合計し百 分率で表したもの)の平均值を算出して用いた。また 心拍数は視覚刺激暴露中の 1 秒毎に測定された值の平 均值を算出して用いた。

点滅周期の違いによる呈示刺激を暴露した際の生理 的効果を検討するため，それぞれの暴露時間中の各脳 波の分布率抢よび心拍数の平均值を算出し, 赤, 緑, 青色光は paired t-test を用い, 黄色光は繰り返しの ある一元配置の分散分析を用いて検討を行った。

\subsection{2 主観評価}

心理的な解析も行うため, 不安感, 緊張感, 快適 性, 覚醒度, リラックス感の 5 項目について「とても 感じた一全く感じなかった」の 5 段階のリッカート法 を用い, 得点が高いほど項目に対する印象を強く感じ ていることを示すものとした

\section{5 倫理的配慮}

本研究は A大学, 研究に関する倫理審査委員会の承 認を受けて行った。研究対象者に対して, 研究の意 義，目的，方法，予測される結果や危険について，文 書ならびに口頭により十分な説明を行った。研究対象 者へは, 内容を理解した上, 同意書への署名を依頼し た。

\section{6 統計処理}

本研究では, データ取得に成功した 16 名を分析対象 とした。それぞれの視覚刺激毎の主観評価, 心拍数, 脳波の分布率の変化について, 赤色光, 緑色光, 青色 光はpaired t-test, 黄色光は呈示刺激を要因とした繰 り返しのある一元配置の分散分析を用いて検討した。 なお，検定は両側検定を用いて $\mathrm{p}<0.05$ を有意とした。 また, 全ての統計処理にはStatical Package for the Social Science (SPSS) ver.19.0 J for Windowsを使用 した.

\section{3. 結果}

\section{1 点滅周期の違いによる黄色光の生理的・心理的効 果の検討}

ホタルの光に近い黄色光で罒 2 に示す 1.2 秒 , 2.4 秒, そして 4.2 秒の 3 種類の点滅周期で呈示した際の 生理的反応, 主観評価における心理的効果を検討し た. 点滅周期の違いによる呈示刺激を暴露した際の生 理的効果を検討するため, それぞれの暴露時間中の各 脳波の分布率および心拍数の平均值を算出し, 繰り返 しのある一元配置の分散分析を用いて検討を行った。

その結果, 表 2 および四 3 に示すように脳波の $\alpha 3$ 波の分布率に有意差を認めた。そこでTukeyの多重 比較を行った結果, 点滅周期 4.2 秒は有意に 1.2 秒と比

表 2 黄色光における点滅周期別（周期 1.2 秒, 2.4 秒, 4.2 秒）生理評価（脳波 $\theta$ 波, $\alpha 1$ 波, $\alpha 2$ 波, $\alpha 3$ 波, $\beta$ 波, の分布率と心拍数)

\begin{tabular}{|c|c|c|c|c|c|c|}
\hline $\begin{array}{c}\text { Flashing } \\
\text { cycle }\end{array}$ & $\theta$ & $\alpha 1$ & $\alpha 2$ & $\alpha 3$ & $\beta$ & $\begin{array}{c}\text { Heart } \\
\text { rate } \\
(\mathrm{bpm})\end{array}$ \\
\hline $1.2 \mathrm{~s}$ & 0.164 & 0.210 & 0.236 & 0.251 & 0.138 & 76.12 \\
\hline $2.4 \mathrm{~s}$ & 0.160 & 0.206 & 0.237 & 0.248 & 0.150 & 76.78 \\
\hline $4.2 \mathrm{~s}$ & 0.162 & 0.207 & 0.238 & 0.245 & 0.148 & 74.14 \\
\hline p-value & 0.269 & 0.101 & 0.937 & 0.048 & 0.069 & 0.022 \\
\hline
\end{tabular}

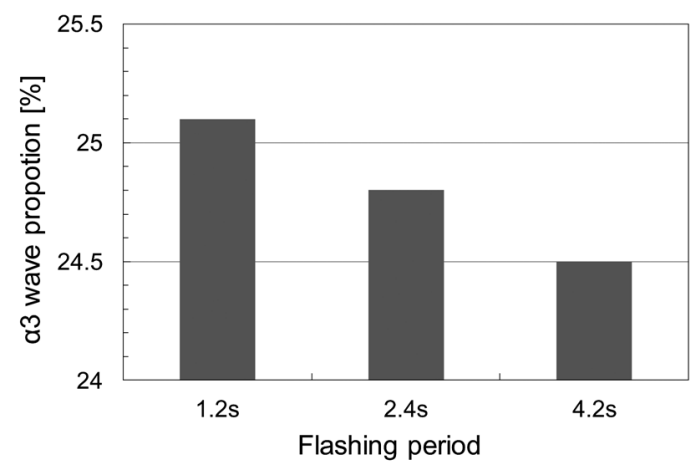

図 3 黄色光の点滅周期別の $\alpha 3$ 波の分布率の平均値 


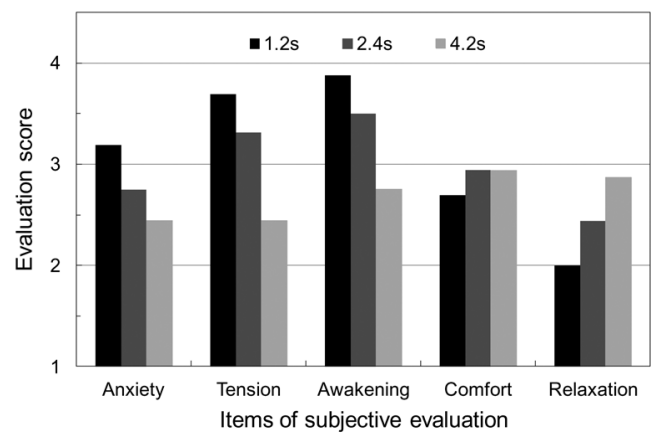

図 4 黄色光の点滅 (点滅周期 1.2 秒, 2.4 秒, 4.2 秒) に打ける主観評価の平均值. 各項目について高 数值ほど強く感じていることを意味している. 点数は $1 \sim 5$ の 5 段階評価である.

べて分布率が低く，長周期に伴い，分布率が減少する 傾向を示した。 心拍数では 2.4 秒周期が 4.2 秒周期より 有意に心拍数が高い結果が得られた $[\mathrm{F}(2,30)=4.381$, $\mathrm{p}=0.022]$.

次に, 心理的効果を比較検討した。その結果を図 4 に示す。不安感, 緊張感, 覚醒度, 快適性, リラック 感(図 4 では各々 Anxiety, Tension, Awakening, Comfort, Relaxation と表記)について点滅周期の違い による心理的効果を繰り返しのある一元配置の分散分 析を用いて検討を行った。な抢有意差の認められたも のについては, Tukeyの多重比較を行った。その結 果, 不安感 $[F(2,30)=5.062, p=0.013]$, 緊張感 $[F(2$, $30)=10.487, \mathrm{p}<0.01]$, 快適性 $[\mathrm{F}(2,30)=0.652, \mathrm{p}=$ $0.528]$, 覚醒度 $[\mathrm{F}(2,30)=6.898, \mathrm{p}=0.003]$, リラック 又感 $[\mathrm{F}(2,30)=7.326, \mathrm{p}=0.003]$ となり，快適性を除 く全ての項目に有意差を認めた. Tukeyの多重比較を 行った結果, 不安感は周期 1.2 秒が有意に 4.2 秒より高 く, 緊張感は周期 1.2 秒と 2.4 秒が有意に 4.2 秒より高 かった。覚醒度は 1.2 秒が有意に 4.2 秒より高く, リラッ クス感は 4.2 秒が有意に 1.2 秒より高い結果となった。

\section{2 点滅周期の違いによる赤, 緑, 青の色光の生理 的・ 心理的効果の検討}

黄色光と同様に, 赤, 緑, 青の点滅光において, 2 種類の点滅周期 (1.2 秒と 4.2 秒)による呈示刺激を曝露 した際の生理的効果を調べた。それぞれの曝露時間中 の各脳波の分布率扎よび心拍数の平均值を算出し, paired t-testを用いて検討を行った。その結果を表 3 ， 4,5 に示す.

その結果, いずれの色光において, 脳波, 心拍数と もに, 点滅周期別で心理的効果に有意差は得られな
表 3 赤色光における点滅周期別生理評価

\begin{tabular}{|c|c|c|c|c|c|c|}
\hline $\begin{array}{c}\text { Flashing } \\
\text { cycle }\end{array}$ & $\theta$ & $\alpha 1$ & $\alpha 2$ & $\alpha 3$ & $\beta$ & $\begin{array}{c}\text { Heart } \\
\text { rate } \\
(\mathrm{bpm})\end{array}$ \\
\hline $1.2 \mathrm{~s}$ & 0.160 & 0.208 & 0.236 & 0.250 & 0.146 & 75.92 \\
\hline $4.2 \mathrm{~s}$ & 0.164 & 0.208 & 0.234 & 0.247 & 0.147 & 74.05 \\
\hline p-value & 0.218 & 0.989 & 0.606 & 0.295 & 0.739 & 0.083 \\
\hline
\end{tabular}

表 4 緑色光に打ける点滅周期別生理評価

\begin{tabular}{|c|c|c|c|c|c|c|}
\hline $\begin{array}{c}\text { Flashing } \\
\text { cycle }\end{array}$ & $\theta$ & $\alpha 1$ & $\alpha 2$ & $\alpha 3$ & $\beta$ & $\begin{array}{c}\text { Heart } \\
\text { rate } \\
(\mathrm{bpm})\end{array}$ \\
\hline $1.2 \mathrm{~s}$ & 0.163 & 0.206 & 0.236 & 0.248 & 0.147 & 75.59 \\
\hline $4.2 \mathrm{~s}$ & 0.159 & 0.207 & 0.242 & 0.247 & 0.145 & 76.00 \\
\hline $\mathrm{p}$-value & 0.165 & 0.472 & 0.051 & 0.404 & 0.649 & 0.670 \\
\hline
\end{tabular}

表 5 青色光に打ける点滅周期別生理評価

\begin{tabular}{|c|c|c|c|c|c|c|}
\hline $\begin{array}{c}\text { Flashing } \\
\text { cycle }\end{array}$ & $\theta$ & $\alpha 1$ & $\alpha 2$ & $\alpha 3$ & $\beta$ & $\begin{array}{c}\text { Heart } \\
\text { rate } \\
\text { (bpm) }\end{array}$ \\
\hline $1.2 \mathrm{~s}$ & 0.156 & 0.210 & 0.230 & 0.263 & 0.141 & 76.17 \\
\hline $4.2 \mathrm{~s}$ & 0.161 & 0.207 & 0.237 & 0.258 & 0.136 & 76.94 \\
\hline p-value & 0.600 & 0.404 & 0.115 & 0.128 & 0.741 & 0.448 \\
\hline
\end{tabular}

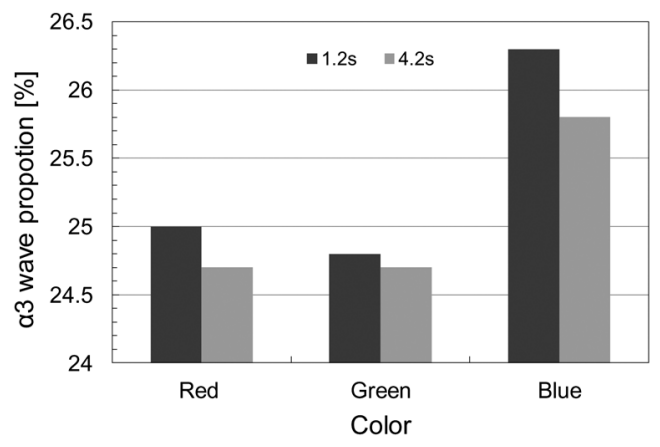

図 5 点滅周期別 $\alpha 3$ 波分布率, (a) 赤色光, (b) 緑色 光, (c) 青色光

かった. 黄色光の場合と同様に $\alpha 3$ 波の分布率を比較 したところ，いずれの色光において短周期である 1.2 秒の方が高い傾向を示し, 黄色光と同様の傾向であっ た(図 5 )。

続いて, 赤, 緑, 青の各色光の点滅周期の違い $(1.2$ 秒と 4.2 秒)に抢ける心理的効果を検討した。 その結果 を図 $6,7,8$ に示す. 不安感, 緊張感, 覚醒度, 快適 性, リラックス感(図 6,7,8では各々 Anxiety, Tension, Awakening, Comfort, Relaxationと表記)について点滅 周期の違いによる心理的効果をpaired t-test を用いて 検討を行った。

赤色光では図 6 に示すように, 不安感, 覚醒度の項 


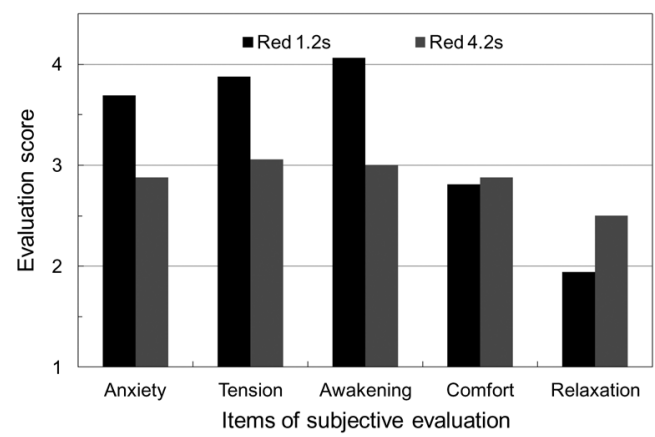

図 6 赤色光の点滅(点滅周期1.2秒と4.2秒)における主 観評価結果, 各項目について高数值ほど強く感 じていることを意味している．点数は 1 ～5の 5 段階評価である。

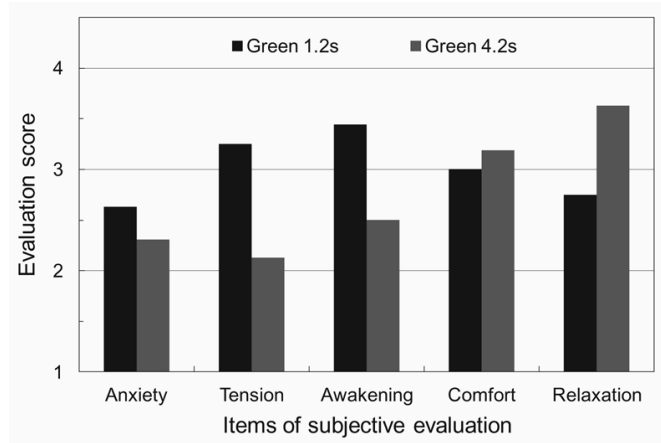

図 7 緑色光の点滅(点滅周期1.2秒と4.2秒)における主 観評価結果

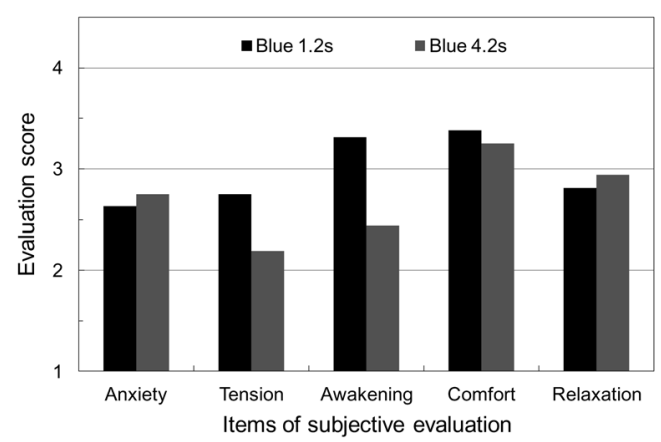

図 8 青色光の点滅(点滅周期1.2秒と4.2秒)における主 観評価結果

目に打いて有意に周期 1.2 秒が高く, リラックス感で は有意に 4.2 秒が高い結果であった。

緑色光では, 図 7 に示すように緊張感, 覚醒度の項 目では有意に周期 1.2 秒が高く, リラックス感では有 意に 4.2 秒が高い結果であった。
そして青色光では, 図 8 に示すように緊張感, 覚醒 度の項目では有意に周期 1.2 秒が高い結果であった。

色光別で見ると, 赤色光の周期1.2秒で不安感, 緊 張感, 覚醒度が平均して高く, 周期 4.2 秒の緑色光と 青色光の快適性, リラックス感が比較的高い結果で あった。

\section{4. 考察}

本研究では黄色光, 赤色光, 緑色光, 青色光の点滅 周期の違いによる 9 種類の呈示刺激を曝露した際の生 理的・心理的効果について検討を行った。その結果, 黄色光に扔いて点滅周期の違いによる心拍数に有意な 差を認めた。

黄色光に関して, $\alpha 3$ 波(周波数 $12 \sim 14 \mathrm{~Hz}$; 緊張し， 集中した状態で，かつゆとりがない状態を示す脳波） では, 長周期に伴って分布率が高くなる結果となっ た. 赤, 緑, 青の色光でも有意な差は得られなかった が, 同様の傾向を示した。本結果は, 短周期では警告 感を, そして黄色光の点滅周期 4.2 秒の呈示刺激が, 黄色光ではホタルの灯等何らかの類似した灯を想起さ せ, 呈示刺激への意識を集中させた結果, 分布率の増 加として認められた可能性が示唆される.

心拍数では, 黄色光に打いて, 点滅周期 2.4 秒が点 滅周期 4.2 秒に比べて有意に高い結果であった。心拍 数は精神的なストレスや肉体的なストレスにより増加 することが指摘されている。精神的・肉体的ストレス を受けるとその刺激が大脳を介して視床下部に伝わ り, 交感神経が優位になることにより心筋収縮力の増 強や心拍数の増加が起こる. 本研究結果でも, 点滅周 期が早いと被験者に緊張感や不安感を高め, 精神的ス トレスを引き起こしたものと考えられる。

心理的効果について評価した結果, 快適性について はどの色相においても点滅周期の違いによって心理的 影響を認めなかったが，緊張感は全ての色相に打いて 点滅周期1.2秒の方が強く感じ, リラックス感は全て の色相に打いて長周期 (4.2秒)になるにつれて高まる 傾向が得られた. 不安感は黄色光, 赤色光に扔いて点 滅周期 1.2 秒の方が強く感じ, 覚醒度は黄色光, 緑色 光, 青色光に扔いて点滅周期1.2秒の方が高まる傾向 が認められ, 生理的効果との相関が示唆された。

色相別の心理評価について, 本来赤色光は覚醒度を 高める効果を有する $[4]$ ことから, 図 $6,7,8$ に示す ように他の色光に比べて高い緊張度と覚醒度の数值が 得られたと推察される。つまり, 赤色光は, 覚醒度を 高め, 集中力を強化する作用を有することが示唆され た. 一方, 緑色光と青色光では, 本来持つ鎮静効果, リラックス効果, そして前回得られた成果 $[19,20]$ を 
含め, 黄色光や同程度の輝度である赤色光と比較して 高い快適性とリラックスの数值となったと考えられる. 加えて, 赤, 緑, 青の色光では黄色光に比べて低輝度 であったことより, 視覚刺激がやや弱化し, 脳波の評 価では有意差が得られなかった可能性が示唆される.

被験者のコメントからも色光に限らず, 長周期の点 滅光では「眠気が高まる」，そして，短周期 (1.2秒)の 点滅では，「チカチカして覚醒感が高まる」という意見 が多く得られた。人間が持つ周期的なリズムとして心 拍数やまばたきなどがあるが, 成人の呼吸数は 1 分間 に16 18回（ $3 \sim 4$ 秒に 1 回に相当)であり，睡眠時に はさらに呼吸数が減ることが知られている $[22,23]$. 本実験の結果で点滅周期が長くなるにつれて, 覚醒度 の度合や $\alpha 3$ 波の分布率が減少し，そして眠気が高ま ることから, 点滅周期に呼吸周期が同調し, 結果とし て眠気を誘発する効果が現れることが推測される。今 後はこの呼吸周期との関連性について検討することも 重要と考えている.

心理的評価から黄色光, 赤色光, 緑色光, 青色光に 共通して認められた傾向として, 点滅周期が早まるほ ぞ緊張感や不安感を強く感じる一方で, リラックス感 を感じにくくなり, 点滅周期が長くなると緊張感や不 安感を感じにくく, リラックス感を感じやすい特性が みられた。つまり, 同色相であっても, 点滅周期の違 いにより, 人が感じる生理的・心理的効果に差異が認 められる可能性が示唆された。したがって, 注意喚起 や警告の際には，どの色相に扔いても点滅周期を早 め, リラックス効果を期待する際は, 点滅周期を長く するなど，目的に応じた点滅周期を選択することでよ り高い効果が期待できるといえる。また，黄色光の点 滅周期 4.2 秒では, 生理的・心理的リラックス効果が 認められた。点滅周期 4.2 秒の黄色光は, ホタルの灯 に類似していることより, 多くの人がホタルの灯に癒 しを感じるのもこの点滅周期が影響している可能性が ある。このことは, 呈示刺激の選択によって, 自然の 中に身をゆだねたようなリラックス効果が期待でき， 癒しの疑似環境の構築の可能性が示唆された。

本研究で使用した点滅光の周波数特性についても調 べ, $1 / f$ ゆぎ現象 (癒しに関連のある現象とされて いる. 光強度の対数值が周波数の逆数に比例すると癒 し効果が高いとされている. 横軸に周波数, 縦軸にパ ワースペクトルをとり，両対数軸でグラフ化すると 右下がりの直線的なスペクトルになる [14-16]) との 相関性についても検討した。 $1 / f$ ゆらぎを持つ音や光 は人間にとって心地良く感じられる現象であり，ホタ ルが発する光も元の 1 つとして一般的に知られてい る。図 9 は図 2 の波形をDFT(Discrete Fourier Trans- form)解析したグラフである.ここでは, サンプリン グ周波数を $100 \mathrm{~Hz}$ ，データ総数を1024としている，横 軸に周波数, 縦軸にパワースペクトルをとり，両対 数軸でグラフ化した。 図 9 に示すように, 各点滅周期 に対応する周波数 (周期 1.2 秒は $0.83 \mathrm{~Hz}, 2.4$ 秒は $0.42 \mathrm{~Hz} ， 4.2$ 秒は $0.24 \mathrm{~Hz}$ である)で強いピークが確認で きる。また， $1 \mathrm{~Hz}$ 以上の各スペクトルに着目すると 周期 2.4 秒と 4.2 秒では, 大きな変動がなく, ほぼ直線 的な減少が確認できるが，周期1.2秒では大きな変動 が多くみられた。

この変動が現れる周波数の境界を調べるため, さら に周期 1.8 秒と 2.0 秒の周波数を計算した。各点滅光は 図 2 で示したように, 光の呈示時間と暗状態の時間を 同等にしている.DFT 解析したスペクトルを図10に 示す. 周期 1.8 秒では, 周期 1.2 秒で確認されたスペク トルの変動がみられるが(罒10の点線丸), 周期 2.0 秒 では確認されなかった。つまり点滅周期 2 秒を境に癒 し効果が大きく変化することが本実験結果から示唆さ れた。

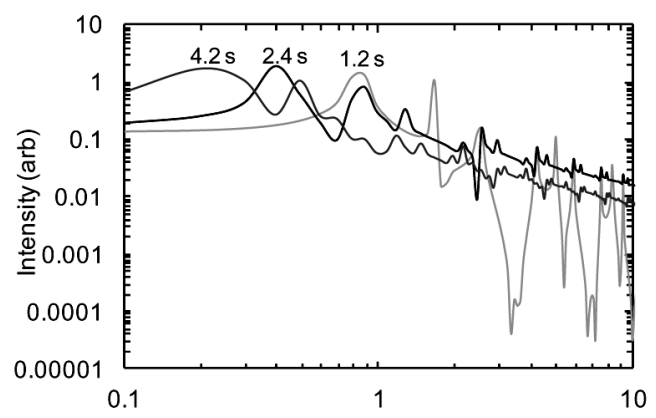

図 9 図 2 に示す点滅波形から計算した周波数特性

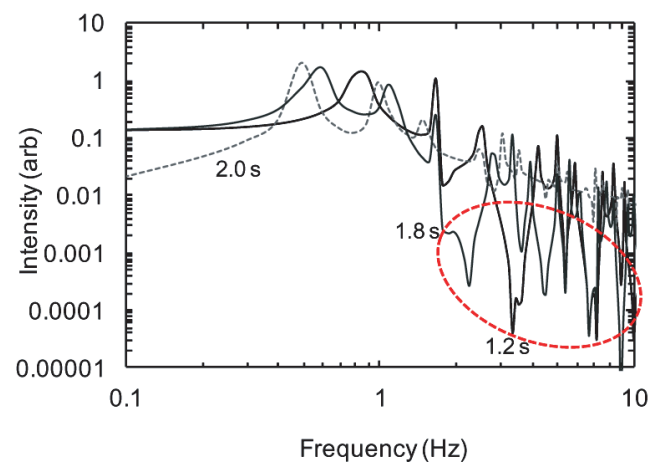

図10 点滅周期1.2秒，1.8秒，2.0秒から計算した周波 数特性.いずれの点滅周期も呈示時間と暗時間 を同時間にしている。 
今回の実験対象者は 20 代前半の男子学生に限定した ため, 今後は性別や年齢層の異なる対象に対し，今回 明らかとなった特性に類似性・共通性が認められるか など更なる検討が必要である。また，呈示刺激などに より瞬間的な交感神経の興奮が起こると，これを抑え るために副交感神経が働き心拍数や血圧は低下する. さらに同一の刺激の連続性や繰り返しによって刺激に 対する反応は減衰・鈍化するという視覚刺激への馴化 は, 人の生理的・心理的反応の全般に見られる現象で ある。その現象には, 刺激の強さ, 大きさ(面積), 持 続時間が関与し，中でも持続時間が最も大きな影響を 与えることが指摘されている。本研究では自律神経の 作用機序を考慮し，色順応効果を極力回避するために 視覚刺激時間の暴露時間を 60 秒と設定した。今回視覚 刺激の差異による生理的・心理的反応の違いが明らか になったことから, 本研究の刺激呈示方法は適切で あったと考えられるが, 今後は刺激呈示方法を変化さ せた際の生理的・心理的反応の違いについても詳細に 検討する必要がある。しかし, 点滅周期の違いによ り，異なった生理的・心理的影響を及ぼす可能性が示 せた本研究結果は, 暗視野に打ける最適なディスプレ イの表示色の基礎データとして活用できるほか, 視覚 情報の特徵を効果的に取り入れた危険認識への応用お よび快適な空間の設計, 構築において一つの示唆にな ると考える。

\section{5. 結論}

点滅周期を変化させた色データにおける生理的・心 理的影響を検討することを目的に，20〜22歳の学生 16名を対象に実験を行った。その結果, 点滅光の影響 を定量的に評価することができ，黄色光で，周期 4.2 秒は 1.2 秒に比べて脳波の $\alpha 3$ 波の分布率が有意に高 く, 主観的評価との相関が認められた。つまり長周期 の点滅周期の点滅光が快適性やリラックス感が高まる 傾向が認められた。今回得られた結果により，ストレ スの低減およびメンタルヘルスの維持・向上に寄与で きることが期待されるため, 増加しつつあるストレス 関連疾患の患者をはじめ, ストレスに起因する心身の 不定愁訴を抱える人々に対し, 病院や企業, 教育現 場，地域社会に打いて癒し効果の高い快適空間に提供 することが可能と考えている。そのためにも今後は液 晶プロジェクタを使用して大画面化, そして大人数に 対して実験を行い，その有効性を調べていきたいと考 えている．また，嗅覚や聴覚を組み合わせた環境でそ の有効性を調べ, 癒しの空間創りを行っていくつもり である。
参 考 文 献

[ 1 ] Noguchi H., Sakaguchi. T.: Effect of illuminance and color temperature on lowering of physiological activity, J. Physiol. Anthropol. Appl. Human Sci., 18, pp.117123, 1999.

[ 2 ] Noguchi H., Sakaguchi T., Sato M.: Physiological effects of sudden change in illuminance during dark-adapted state, Appl. Human Sci., 18, pp.109- 114, 1999.

[ 3 ] Yoto. A., Katsuura T., Iwanaga. K., ShimomuraY.: Effects of object color stimuli on human brain activities, J. Physiol Anthropol, 26, pp.373- 379, 2007.

[ 4 ] Katsuura T., Yasuda T., ShimomuraY., Iwanaga K. : Effects of monochromatic light on time sense for short intervals, J Physiol Anthropol, 26(2), pp.95-100, 2007.

[ 5 ] Miyaho N., Konno N. Shimada T.: Study on healing environment using green, blue and red LED and aroma, Journal of light and visual environment, 32 , pp.97-102, 2008.

[6 ] Noriharu M., Noriko K., Takamasa S. : Study on healing environment using green, blue and red LED and aroma, Journal of light and visual environment, Journal of light and visual environment 32 (2), pp.97-102, 2008.

[ 7 ] Naveen, K. V., Shirley, T.: Psychophysiological effects of colored light used in Healing. World J. Med. Sci., 1 (1), pp.21-23, 2006.

[ 8 ] 三谷明美, 田中マキ子:光刺激 (LED) によるリラクセー ション効果の検証, 山口県立大学学術情報 3 , pp.33$38,2010$.

[ 9 ] O'Connor Z.: Colour psychology and colour therapy, Caveat emptor Color Research Application, 36 (3), pp.229-234, 2011.

[10] http://www.sharp.co.jp/led_lighting/ceiling/

[11] http://www.segatoys.co.jp/homestar/earth_theater/

[12］武者利光：ゆらぎの世界, 講談社（1991）

[13］加藤和夫, 志子田有光, 望月菜穂子, 石川敦雄, 小林 宏一郎, 小林哲生：視覚情報の差異に伴う心的活動変 化の自発脳波律動に基づく評価の試み人間工学， 44 (2) , pp.67-75, 2008.

［14］干場恵美子, 稲垣照美, 木村尚美, 阿部宣男, 宮内一 美：ホタルの発光パターンに打色相の $1 / f^{n}$ ゆ き現象と癒し効果, 日本機械学会論文集C編, $72(714)$, pp.409-417, 2006.

[15] 稲垣照美, 犬塚浩二, 安久正紜他：ホタルの発光パ

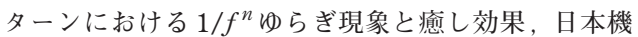
械学会論文集 C，67（657）, pp.365-372，2001.

[16] 阿部宣男, 稲垣照美, 石川秀之, 松井隆文, 安久正紜: ホタルの光と人の感性についてー発光現象のゆらぎ特 性, 感性工学研究論文集 3 (1), pp.35-44, 2003.

[17］稲垣照美, 安達政伸, 阿部宣男: ホタルの光と人の感 性について一生物情報に基づいた, 光音相互変換シス テムの開発と福祉応用, 感性工学研究論文集 6 (1), pp.61-71，2005.

[18］阿部宣男, 稲垣照美, 木村尚美, 松井隆文, 安久正紜： ホタルの光と人の感性について感性情報計測と福祉応 用，感性工学研究論文集 $3(2), p p .41-50,2003$.

[19］山下真裕子, 山田逸成, 安田昌司: 色相およびトーン を変化させた色光に打ける生理的・心理的影響, 日本 
感性工学会論文誌, 12（2）, pp.239-243，2013.

[20] Yamashita M., Yamada I., Yasuda M.:"Psychophysiological effects of tones of coloured lights Yamashita Mnment”, NES2012 Proceedings, Yamashita_M-16,2012 .

[21] Poelman. D., Avci. N., Smet. PF. : Measured luminance and visual appearance of multi-color persistent phosphors, Opt. Express, 17, pp.358-364, 2009.

[22] Snyder F., Hobson J. A., Morrison D. F., Goldfrank F. : Changes in respiration, heart rate, and systolic blood pressure in human sleep, Journal of Applied Physiology, 19 (3) , pp.417-422, 1964.
[23］太湯好子, 菊井和子：基礎看護学, ふくろう出版, pp.77$78,2006$.

（2014年12月 3 日 受付）

(2015年 1 月22日 採録)

[問い合わせ先]

于238-8522 神奈川県横須賀市平成町1-10-1

神奈川県立保健福祉大学 保健福祉学部看護学科

山下 真裕子

TEL : 046-828-2620

FAX : 046-828-2621

E-mail : yamashita-nyg@kuhs.ac.jp

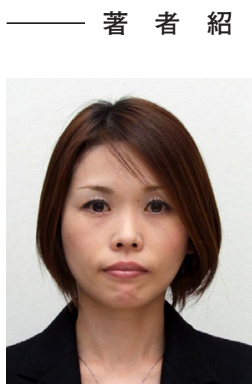

\section{山紫埧裕子 [非会員]}

2008年広島大学大学院保健学研究 科修了, 保健学博士. 広島大学病院, 医療法人社団更生会草津病院で看護師 としての臨床を経て，2009年滋賀県 立大学人間看護学部助教, 2012 年神 奈川県立保健福祉大学講師, 現在に至 る。現在はうつ病患者への看護支援 や, 精神障害者のセルフマネジメント サポートシステムの構築等の研究に従 事.

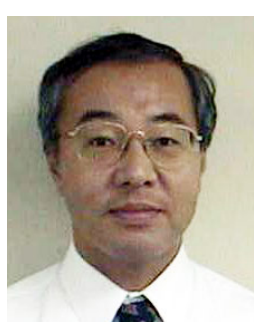

\section{管奋㬱司 [正会員]}

1980年京都大学大学院工学研究科 修了，1995年京都大学博士。三洋電 機 (株)研究所長を経て, 2008年滋賀 県立大学教授, 現在に至る。専門は知 能システム制御。応用として, 人間感 覚計測応用技術, 遠隔ケアシステム, 非接触 $3 \mathrm{D}$ 生体計測を開発。2008年日 本感性工学会技術賞, 2003年システ 么制御情報学会産業技術賞.

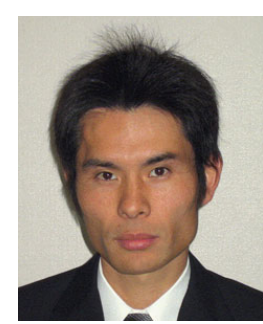

やまだ いっり 冕成 [非会員]

2000 年大阪大学大学院工学研究科 博士前期課程修了. 同年三洋電機株式 会社入社. 2008 年龍谷大学大学院理 工学研究科博士後期課程修了. 同年産 業技術総合研究所に入所. 2010 年よ り滋賀県立大学工学部助教, 2014年 より准教授. 微細加工技術を利用した 光学素子の研究開発に従事. 博士 (工 学) 


\section{Psychophysiological effects of colored lights for change of flashing cycle by}

\section{Mayuko YAMASHITA, Itsunari YAMADA and Masashi YASUDA}

\section{Abstract :}

Psychological and physiological effects of colored lights for change of flashing cycle were examined using a liquid crystal display in a dark environment $(<0.1 \mathrm{~lx})$. The colored lights were characterized with various flashing cycle, i.e., flashing cycle were selected the range of 1.2-4.2 s. To investigate psychological and physiological effects, we used electroencephalography, heart rate and a simple questionnaire. Subjective evaluations of 'comfort', 'relaxation', 'awakening', 'tension', and 'anxiety' were conducted using a five-level psychological preferences evaluation. Electroencephalographic, heart rate and psychological evaluations revealed that the slower flashing cycle had a good effect for relaxation. Colored lights with the earlier flashing cycle enhanced the degrees of tension and anxiety. Results of this study are effective for providing healing environment to patients with severe stress.

Keywords : colored light, flashing period, psychological, physiological effects

\section{Contact Address : Mayuko YAMASHITA}

School of Nursing, Kanagawa University of Human Services

1-10-1, Heiseicho, Yokosuka, Kanagawa, 238-8522, Japan

TEL : 046-828-2620

FAX : 046-828-2621

E-mail : yamashita-nyg@kuhs.ac.jp 